\title{
MULTICULTURAL EUROPE: THE CASE OF BULGARIA
}

\author{
Gabriela Belova BELOVA-GANEVA \\ iD: https://orcid.org/0000-0001-6988-3452 \\ South-West University "Neofit Rilski”, Blagoevgrad, Bulgaria
}

\section{Gergana Vasileva GEORGIEVA}

https://orcid.org/0000-0002-1396-6889

South-West University "Neofit Rilski”, Blagoevgrad, Bulgaria

\section{ABSTRACT}

The article aims at analyzing the cultural and linguistic diversity in Europe as values worth being preserved since they are a guarantee for open consciousness. Multiculturalism and multilingualism contribute to the goals of job creation and sustainable growth. Multilingualism, which is a vital and integral part of Europe's rich and cultural diversity, is a way out of the deep crisis that has gripped Europe because the continent is a huge labor market, where English is the working language, but knowledge of a universal language is not enough. The paper emphasizes upon a very significant issue whose essence is: the task of our time is to be able to realize that the unity of the human race lies in diversity. It is therefore not accidental that the motto of the European Union states "United in diversity". The case of Bulgaria as a part of the European Union is also scrutinized in the article. Bulgarians have lived for centuries at a crossroads between Europe and Asia along with various peoples and ethnicities. This serves as an explanation as to why the Balkans are a multicultural region despite the fact that it was often associated with fragmentation and wars. An inference has been drawn that it is apparent the modern Bulgarian people can find their identity at the European Union level, at the Balkans' level, at the level of the Bulgarian tradition, even at the level of the local community. And it is feasible to have productive cooperation between these levels of identities.
ARTICLE INFO

ARTICLE HISTORY

Received:

12 November, 2020

Accepted:

5 April, 2021

Published:

25 April, 2021

Available online:

25 April, 2021

\section{KEYWORDS}

Multicultural

European Union, multilingualism, multilingualism. CJEU, Bulgarian nation 


\section{Introduction}

Studies on the importance of Europe, European values and European identity have inevitably raised and continue to raise multifold controversial issues at the beginning of the 21 st century. Is the European "project", as presented by the European Union (EU), ultimately based on sufficiently shared values, culture and history? What kind of Europe are we building and why? How does this new Europe relate to the models and experiences of European history? Is the very diversity of national and regional cultures the main reason for European affiliation? As some researchers point out, until the 1950s, Europe was never united in its existence, and its history is a history of fragmentation and conflicts (БеловаГанева, 2008). The promotion of multilingualism in the various policies of the European Union - culture, education, communication and employment - is one of the Union's main objectives.

The EU formally takes responsibility for respecting the cultural and linguistic diversity of its citizens. This is done in several ways: 1) by respecting our right to speak and write in our own language and extending its scope to our relations with the EU institutions; 2) by supporting the use of regional and minority languages, whether or not they are official EU languages; 3) by actively promoting foreign language learning and multilingualism as a means of individual self-improvement for European citizens and the creation of new jobs as well as the overall growth of the EU economy.

\section{Nation - origin, language and culture}

Victor Hugo's idea of a "United States of Europe", today the European Union, is directly linked to a union called the "United States of America". In connection with the present study, the authors allow themselves to note the multilingual model of the EU, which opposes the monolinguistic model of the United States. The American nation has historically been formed by people belonging to different nations. And the hallmarks of a nation are a common origin, language and culture. For the German philosopher Herder ${ }^{1}$ however, all groups are equally valuable and have a place under the sun. He denies the superiority of one nation over another, believes in the diversity of national cultures and their peaceful existence. Language and culture represent the inner synchronicity of nations that are much more than the sum of their members: spiritual human communities, collective individuals, a divine idea. According to Herder, each national group has its own spirit - Volksgeist or Nazionalgeist (Hamilton, 2011), a complex of customs and way of life, specific behavior and perception, which it values because it is its own.

\footnotetext{
${ }^{1}$ Johann Gottfried von Herder is a German philosopher, poet, literary critic, theologian and translator associated with the ideas of the Enlightenment. He influenced Johann Wolfgang von Goethe and Friedrich Schiller. He is called the "father of cultural nationalism". In 1963, the so-called Herder Prize was established, which was awarded each year to 7 European scientists and cultural figures for promoting cultural relations with the peoples of Eastern and South-Eastern Europe, as well as for preserving Europe's cultural heritage in the spirit of peaceful understanding. The decision on who to award the prize to is made by the University of Vienna. The Gottfried von Herder International Prize closed in 2006.
} 
In a similar way, the Bulgarian lawyer and constitutionalist Lyubomir Vladikin during the Second World War pointed out that "the people, this is the sum of all the subjects of the state" (Владикин, 1992).

The sum also includes temporary residents abroad, as well as people with dual citizenship. The term "people" inevitably requires consideration of the question of the nation that originated from the tribe. The people are a union of several blood and culture related tribes - Vladikin writes, although the Bulgarian history shows that kinship can take place between completely different or opposite races and tribes. In any case, the characteristics of the nation are: common tribal (racial) origin, common religion and language, common external environment, common state, common customs and traditions, a common culture.

A number of authors try to propose a definition of "nation". Sociologist Alfred Vierkand $\mathrm{t}^{2}$ notes that this is the equality of language and culture in general, the real relations of communication and personal touch (Mitscherlich, 1931). The French philosopher and historian Maurice Hauriou describes the nation as "a grouping of primary ethnic entities in which long-term coexistence in the same land, combined with a certain community of race, language, religion and historical memories, has created a spiritual community that serves as a basis of a higher formation (Gray, 2012). From a philosophical point of view, it is difficult to draw a line between the terms "people" and "nation". The marks of the nation are also the marks of the people.

In place of pre-existing feudal or agrarian societies, which are characterized by diversity in language, culture and ethnicity, the industrial society requires a homogeneous civil society with a pervasive universal high culture (i.e. standardized literary and educational communication system) as a condition for its effective functioning (Тодоров, 2000). This is achieved in the first place by introducing a unified education that prepares a universal workforce for industrial enterprises. However, in order for the education system to function, a single language must be adopted, which will make it possible to achieve the degree of mobility of the population and division of labor that the industrial economy requires (Ibid., p. 87). This leads to a change in the structure of the state, which follows the new economic conditions. Many medieval states were weak in terms of the central government, and governance was exercised through semi-dependent feudal lords, aristocrats, and the church. In large monarchies such as England and France, which impose a strong central authority over their territory and the church, a single culture through a common state language and a single education are not introduced. They do not restrict the population in individual areas from receiving partial education in their languages. Only a small part of the elite is highly educated (Ibid.).

In order to achieve equalization in the level of economic and political development in industrial society, the state must become highly centralized and administratively introduce a state educational system. The industrial economy requires the population to move and work freely wherever they wish, without obstacles of a religious or linguistic nature.

2 Alfred Vierkandt is a German sociologist, ethnographer, social philosopher and philosopher of history. He is a Professor of Sociology at the University of Berlin. 
This determines the transformation of feudal states into modern ones with centralized sovereign power. It is this type of state that introduces a unified education and a unified legal framework is able to displace the local culture and local traditions, as well as to unite the ethnically diverse population in a nation. In this way, according to Gellner ${ }^{3}$, the nation-states are formed. Where the principle of "one state - one culture" is rejected, national movements emerge among individual peoples (Gellner, 1983).

The issues of the development of the ethnic, peoples and national consciousness among the Bulgarians are the object of attention in several works of Dimitar Angelovi. The author considers the concept of "ethnicity" in a narrow and broad sense. In a narrower sense, it represents a community of people who are bearers of a common language, culture and selfawareness as hallmarks (Тодоров, 2000). In a broad sense (historically) ethnic groups build certain social structures, defined as ethnosocial organisms, corresponding to the stages of development of the tribe, nationality and nation. Angelov considers as the main features of the nation the language, which has both ethno-integrating and ethno-differentiating influence; culture (material and spiritual), which is specific and sustainable in nature and is passed down from generation to generation; historical memory; common religion and common national self-consciousness (Ibid., p. 26). In order for a human community to develop in a nation, it is necessary to have a common territory on which to establish lasting economic, political and spiritual ties among the members of one or several ethnic groups; creation of a state organization that plays the role of a strong ethnic-forming factor; and development of economic life (Ibid.). These three main factors for the formation of the nation are accompanied by additional, concrete historical factors such as religion, the presence of unified writing and literature, the development of a layer of educated people, a common language, etc.

\section{Bulgarian nation}

The final formation of the Bulgarian nation, which is characterized by a common literary language, a certain material and spiritual culture, a clear national identity and a single national name consists of the middle of the $9^{\text {th }}$ to the beginning of the $10^{\text {th }}$ century. A significant consolidating role in this process was played by the perception of the common religion in the Bulgarian state (865), as well as the introduction of unified writing, education and literature (Ibid., p. 27). In later research, D. Angelov presents some new objective and subjective facts or factors necessary for the development of ethno-organisms. He emphasizes the common territory first, then the common language, followed by the state structures.

\footnotetext{
3 Ernest André Gellner (9 December 1925 - 5 November 1995) was a British-Czech philosopher and social anthropologist.

${ }^{4}$ Dimitar Simeonov Angelov is a Bulgarian historian and doctor of Byzantine history at the University of Munich. He is an associate professor and professor at Sofia University, a corresponding member and academician of the Bulgarian Academy of Sciences (BAS).
} 
An interesting and original thesis is developed by Strashimir Dimitrov ${ }^{5}$, who is the author of the paragraphs on the development of the Bulgarian nationality and nation from the 15th to the 19th century in the first volume of Ethnography of Bulgaria. He advocated the unfinished process of Slavicization of part of the Bulgarian ethnic component in the eastern borders of the Bulgarian state until its fall under Ottoman rule, which remained Turkishspeaking (Тодоров, 2000). With the arrival of settlers from Asia Minor into the Balkans in the 15 th and early 16th century led to linguistic returkization, and hence to easy Islamization and assimilation of these surviving Turkish-speaking Bulgarians mainly from Eastern Bulgaria in the emerging Ottoman-Turkish nation. Considering the formation and development of the Bulgarian nation since the 18th century, the author emphasizes the specifics of the process and examines in detail each of the factors that determine it. One of them is the development of the Bulgarian language, its transformation into a national literary language in its written and oral form and the establishment of the modern Bulgarian literary language.

Maria Todorova ${ }^{6}$ describes how nationalism is intertwined in the historical development of post-liberation Bulgaria. The publications of Snezhana Dimitrova and Naum Kaichev, as well as Maria Radeva have the same orientation but emphasizing the forms of nationalism presented in the Bulgarian history textbooks as a direct reflection of the domestic political development of Bulgaria for a century, from 1878 to 1996.

Varban Todorov offers the following formula regarding the complex ethnic issues: ethnicity or tribe + state (state formation) = people, nationality; people + modern state $=$ nation. The author is of the opinion that in specific circumstances a nation without a modern state is also equal to a nation. The issues of ethnic group (ethnicity), people, nation should be considered as an interconnected process that develops under the influence of various factors (Ibid., p. 129, Dimitrova and Kaichev, 1999). Georg Jellinek7 explains that the people are a subject of state power, but also an object of this power (Дюги, Малберг и Йелинек, 1993). The nation-state is an institutional form of the subject in international relations, and the evolution of the subject can also fit into the cycle from universalism, (Хинкова, 2010) through national diversity and languages to globalization.

Multilingualism is the cultural and democratic basis of the European Union. Although languages, literature, theater, cinema, radio and television, crafts, fine arts and others originate in a particular region or country, they are part of the pan-European cultural heritage. The European Union pursues a policy of promoting linguistic diversity in various dimensions. On the one hand, multilingualism means the considerable linguistic richness understood as part of Europe's cultural diversity. On the other hand, multilingualism means the ability to express oneself in different languages. The EU is united in its view that linguistic diversity is a key element of European competitiveness. It is no coincidence that the objectives of the European Union's language policy include the fact that every European citizen should know two languages other than their mother tongue.

\footnotetext{
${ }^{5}$ Strashimir Dimitrov is a Bulgarian historian, corresponding member of BAS. He is the author of numerous reviews and translations of scientific publications and articles.

${ }^{6}$ Maria Todorova is a professor of history at the University of Illinois at Urbana-Champaign.

${ }^{7}$ Georg Jellinek is a German scientist and lawyer. He is the author of the work General Doctrine of the State.
} 
Multilingual and Multicultural Legal Reasoning in the Judgments of the Court of Justice of the European Union

Multilingualism in Europe studied through the idea of European unification leads to the conclusion that there is an evolution in communication between European citizens.

Language, as an integral part of national self-consciousness, is also a direct expression of our culture. It demonstrates that the European Union is committed to preserving multilingualism aimed at speaking and writing in the language of the Member State concerned. This also defines the fact that the programs, projects and activities of the European Commission and the European Parliament are developed in accordance with the national policies of all Member States and increase the opportunities for learning foreign languages, including regional and minority languages in the Union. An example of this is services that facilitate the strengthening of multilingual communication in Europe, operating through directorates-general - translation and interpretation. The analysis of their work testifies to the efficiency and better communication between the institutions and the citizens.

Language and culture are interlinked - so the aim of protecting and promoting one or more of the official languages does not need to be followed by other cultural criteria, so as to justify restricting one of the fundamental freedoms guaranteed by the Treaty ${ }^{8}$.

The role of the Court of Justice of the European Union (CJEU) in finding an interpretation in judgments that can be accepted across linguistic, systemic and cultural boundaries is extremely important.

Very often translators shorten the distance of knowledge between two groups of people separated by culture and language. To reach an agreement on the most reasonable solution that can be made, regardless of the cultural or linguistic background of the interpreters, requires more than a linguistic argument from the CJEU, especially in cases where, taken separately, different language versions seem to draw attention to different interpretations.

The problems cannot be solved by using an EU database with shared EU concepts, as each Member State of the Union uses its own legal system, style and adopted register. It also has its own rhetorical, social and cultural requirements, and in order to be a valid EU-derived document, as well as effective in the local legislation of the new Member States, it must go through a process of adapting and reworking a text created by an international organization and socio-cultural characteristics of different national target users. Finally, readers could be reminded of translation difficulties, limitations and the socio-cultural impact on societies and thus will be vigilant about the need for a future interdisciplinary approach to multilingual legal communication in today's globalized society.

\footnotetext{
8 The Treaty of Lisbon reinforces the element of respect for linguistic diversity. For example, Article 3, para. 3 of the Treaty on European Union (TEU) regarding the tasks of the Union in the future states: "It shall respect its rich cultural and linguistic diversity, and shall ensure that Europe's cultural heritage is safeguarded and enhanced". With the entry into force of the EU Reform Treaty, the Charter of Fundamental Rights of the European Union also becomes legally binding (Art 6. of the Treaty of Lisbon in TEU).
} 
When studying the structure of the text - semantic relation (cohesion) - general, cultural and linguistic characteristics are taken into account. Factors contributing to the cohesion of the text are repetition, partial repetition, parallelism, paraphrase, ellipse (omission), time, connection, proforma.

The concepts of people who speak different languages and live in different cultures would be closest if individuals intend to form the same or similar concepts from the same or similar experiences and the experiences of different people from different EU Member States are sufficiently similar. Using a slightly different vocabulary, researcher Engberg explains this problem very precisely (Engberg, 2004). Therefore, the probability of identical concepts has both an inherent component (our cognitive scheme) and a cultural one (how culture shapes experience and presents it in the language of that culture).

The researcher Engberg (Ibid., pp. 1137-39, 1157-61, 1165-66) analyzes Commission of the EU v. United Kingdom (Case 100/84, Commission of the E.U. v United Kingdom, 1985 E.C.R. 1169) - a case involving the conceptualization of fishing. British fishermen commit to joint fishing expeditions in the Baltic Sea with Polish fishermen (Ibid. 2.). British vessels cast their nets; then the Polish vessels began fishing; Polish vessels transmit nets to British vessels that take the fish on board (Ibid. 3.). If these fish are considered to have been caught by Poles, then a duty will have to be paid (It is about the time before Poland's accession to the EU. It is a third party and therefore a duty is due. Ibid. 4.). If they are caught by the British, there will be no tax (Ibid.).

The English version of that regulation states that, first, 'goods wholly acquired or produced in a country will be considered as originating in that country' (Ibid. 7.); and second, that the expression 'goods wholly obtained or produced in a country' means "products of sea fishing and other products taken from the sea by vessels registered or recorded in that country and traveling under its flag» (Ibid.). The Commission claims that the Poles "acquired" the fish because they were the ones who separated the fish from its natural habitat (Ibid. 11.). The British argue that "taken from the sea" should be taken literally and that the fish do not leave the sea until the British fisherman picks up the nets containing the fish caught by the Poles (Ibid. 11-12.).

To address the issue, the Court considered a number of different language versions, but without success (Ibid. 15-16.). The French extraits de la mer is subject to two interpretations: taken from the sea and separated from the sea (Ibid. 15.). Other versions, including Greek, Italian and Dutch, are just as ambiguous (Ibid.). The German word "gefangen", which means "caught" is more useful for the Commission's position (Ibid.). The Court acknowledges that "a comparative examination of the various language versions of the Regulation does not allow a conclusion to be drawn in favor of any argument put forward and no legal conclusions can be based on the terminology used" (Ibid.). Anthony Arnull notes that this is the Court's typical approach in such situations (Arnull, 1999). 
In that case, the Court determined, without the aid of a comparative analysis of the various language versions, that holding the British vessel responsible for the tariff was more compatible with the purpose of the regulation (See 1985 E.C.R. 1169 of 18-22.). The opposite result would allow Member States to "play" with the regulation by doing with impunity what the regulation seeks to ban: imports of fish caught by non-EU members without penalty (Ibid. 19-21.). The Court, therefore, relies on arguments based on coherence as a substitute for the legislative purpose (Ibid. 16-22.).

What is actually going wrong? As already mentioned, the multilingual interpretation of the legislation is essential by nature. As there is no single text, there should be a specific message that a number of texts, taken as a group, are trying to convey. The significant overlap of meaning implies that communication is likely to succeed. However, when Lawrence, as a local English speaker, mentions fishing, he says he does not really know if the essential element is getting the fish out of the water or catching the fish. It never mattered much to him (Lawrence, 2009). Probably both are part of the essence or maybe they are an alternative part of the essence. If what is true of him is true of many other people in his culture and of many people in many similar cultures where German and Romance languages are spoken, then it would not be surprising to find confusion on the "board" alone with several languages taking a stand on the issue - perhaps as a matter of chance, perhaps for more interesting cultural and historical reasons.

What can be deduced from this case is that the Augustinian meaning ${ }^{9}$ does not work to clarify the concept when the dispute requires taking a position on a complex aspect of the concept that is not resolved in a cultural or individual way. If the nature of fishing is not universal, and if experience, in general, allows us to focus on both aspects of the activity with more and less attention, then comparing different language versions will only teach us that the clear statement of a particular version in one direction or another is likely to be secondary and should be ignored. Therefore, the Augustinian methodology, even when it does not give us an unambiguous answer, can warn of conclusions from the clarity of any particular version.

The conclusion that Babylon actually serves to clarify communication is surprising, especially for a member of the American academic community who is accustomed to an environment where at most two languages are spoken and who comes from a culture in which textual analysis predominates, as in the interpretation of laws and contract law (Георгиева, 2019). Nevertheless, the happy ending is precisely this: Augustine is right when he observes that a careful study of the different translations of the same text is likely to lead to a deeper understanding of the true meaning of the text. And it is quite frequent that culture plays an important role for understanding a specific reasoning and then making a final judgment on a case. As it is obvious from what has been describes, this multilingual jurisprudence of CJEU is the outcome of a long process of different legal systems, cultures, customs and languages.

\footnotetext{
${ }^{9}$ A multilingual approach to the interpretation of laws known as an "Augustinian approach".
} 


\section{Cultural Interactions and the Balkans}

Multiculturalism itself has traditionally been seen as an opportunity for tolerant coexistence of different peoples and their cultures, of the main ethnicity with minority groups in the framework of the national state. In this sense, it hardly deserves a negative appreciation. The same applies to the perception of the idea of 'universalism' as a multilateral development of societies and personalities, which categorically denies and opposes any intolerance, racism and xenophobia.

In fact, Bulgarian nationalist idea, despite the fact that it had been formulated in the second half of the $19^{\text {th }}$ century as a plan to deliberate from the Turkish yoke, has never been at odds with concepts such as 'multiculturalism' and 'tolerance'. This is evident in the series of constitutional projects from the second half of the 1960s, as well as after the April Uprising of 1876 (Паев, 2016). Bulgarians have lived for centuries at a crossroads between Europe and Asia together with many other peoples and ethnicities. This explains why the Balkans are a multicultural region although it was often associated with fragmentation and wars (Алипиева, 2019).

With regard to the nationalisms of the end of the last and the beginning of this century, there could be seen some dynamic in Bulgaria, probably as everywhere else. The last decades of the $20^{\text {th }}$ century were revolutionary and conflicting. They were marked by a collision between the fading socialist internationalism and the imported from the West multiculturalism, whose roots were too fragile at the beginning of our democratic path.

The period from the collapse of the socialist block till Bulgaria's accession to the EU in 2007 is vague, emotional, and sometimes contradictory in terms of national values, which were opposed by the European ones.

Especially in the 1990s attitudes towards nationalism within the society were polar. Already at the dawn of democracy in 1991, Tsvetan Todorov, Bulgarian philosopher, historian and sociologist published his article Comments on the Intersection of the Cultures, the main ides of which had been the author's warning (of course, based on his own experience) that Europe is a great illusion (Тодоров, 1991).

\section{Multiculturalism after Bulgaria acceded to the European Union}

The prospects for Bulgaria's accession to European modern culture were first pointed out by Prof. Ivan Shishmanov ${ }^{10}$ who is considered an ambassador of the European idea. He was the first to profess a commitment to the idea of pan-Europeanism as the prototype of today's European Union.

\footnotetext{
10 Prof. Ivan Dimitrov Shishmanov (1862-1928) was a philologist, writer and lecturer, as well as a Bulgarian politician from the People's Liberal Party. He was the founder and first chairperson of the Bulgarian section of the PanEuropean Union. He was a member of the Macedonian Scientific Institute and was the first Bulgarian ambassador to Ukraine.
} 
Since Bulgaria's accession to the EU, multiculturalism has already been formalized and turned into political doctrine. The mere fact that it became obligatory turns the attitude from desirable ideology it became a reality, and this undoubtedly opens the door to the strong Euroscepticism. A number of events and processes fuelled this - geopolitical tensions, waves of refugees, co-existence of diametrically different cultures, terrorism, economic problems, minority rights protection, etc. (Ilieva, 2008).

Thirty years ago, for many Europeans multiculturalism was equal to the idea of an inclusive, diverse society - a response to social problems in Europe. Today, more and more of them consider it the biggest reason for the deteriorating socio-economic development.

Recently, criticism of multiculturalism has become a fashion political trend in Europe. Over the past few years, a number of European leaders have acknowledged that the politics of multiculturalism have failed to integrate immigrants. As some authors point out in recent years, a number of events and processes have unlocked the growth of nationalism and the increase of its public support as a response to the fear of replacing the values and identity of European societies (Marin, 2015).

The world comes to new geopolitical reality and confrontation axes. Leaders such as Angela Merkel, David Cameron and Nicolas Sarkozy after the first decade of the $21^{\text {st }}$ century started to speak about the failure of multiculturalism and its rejection. 'Tolerance' and 'political correctness' lower their masks of demagogy and the redistribution of territories, labour and natural resources have been initiated (Малик, 2016).

On October 17, 2010, Chancellor Angela Merkel said Germany's multicultural model had failed. Speaking at a forum of the youth organization of the Christian Democratic Union (CDU), she stressed that Germany should not only help immigrants but also demand from them. They must respect German laws and master the German language (Тахир, 2016).

Former British Prime Minister David Cameron, who has acknowledged that longstanding policies of multiculturalism are a failure, also spoke out and called for better integration of young Muslims to contain extremism (Ibid.).

The same wording that multiculturalism has failed was used by Nicolas Sarkozy in an interview with one of France's TV channels on February 11, 2011.

The world-known American political scientist Francis Fukuyama has pointed out that it is extremely difficult to create a sense of identity and community outside the national state. One of the biggest problems for the European Union is its incredibly technocratic approach. For decades the European leaders have laid emphasis only on economic integration and failed to take care of creating a deeper European identity, the author also stressed. And in times of crisis usually there is a rise in Eurosceptics and right-wing populists. In short, a naked economic integration is not enough, concluded Fukuyama (Туман и Асхойер, 2016). 


\section{Conclusion}

In conclusion, the ethnocultural diversity of humanity is an undeniable fact. Ideas emerging in the individual countries on this occasion (such as the well-known Canadian multiculturalism) should not be disseminated and applied mechanically in other countries and territories without taking into account local specifics. This will only lead to adverse consequences for the society concerned.

At the same time, it is obvious that the modern Bulgarian people can find their identity at different levels: at the European Union level, at the level of the Balkans, at the level of the Bulgarian tradition, even sometimes at the level of the local community. And it is definitely possible to have productive cooperation between these levels of identities (Знеполски, 2002).

\section{Disclosure statement}

No potential conflicts of interest were reported by the authors. 
References and notes:

Алипиева, А. (2019). Мултикултурализъм, плурализъм, толерантност - конюнктури и реалност,https://liternet.bg/publish/aalipieva/literaturanacionalizym/multik ulturalizym.htm.

Белова-Ганева, Г. (2008). Европейска интеграция, София, СИЕЛА, с. 7-8.

Владикин, Л. (1992). Общо учение за държавата, София, 1992, с. 183-190.

Георгиева Г. (2019). Мултилингвизмът - основен принцип на европейска интеграция, ISBN: 978-954-2977-53-7, София, изд. Диомира, с. 147.

Дюги, Л., Малберг К. и Йелинек, Г. (1993). Общо учение за държавата. Изд. Софи-Р София.

Знеполски, И. (2002). Балканите - криза на идентичностите и междукултурни комуникации.

Кръгла маса с участието на Ивайло Знеполски, Богдан Богданов, Георги Фотев, Ивайло Дичев и Светлозар Игов. // Култура, бр. 19/20, <http://www.kultura.bg/media/my_html/2227/masa.htm>.

Малик, К. (2016). Провалът на мултикултурализма, https://www.marginalia.bg/aktsent/provalat-na-multikulturalizma/.

Паев, К. (2016). Търновската конституция в светлината на балканския конституционализъм от ХІХ век, изд. Сиби, с. 128-129.

Тахир, М. (2016). Мултикултурализъм - конвергенция и/или дивергенция,

http://www.librev.com/index.php/discussion-culture-publisher/2960-2016-04-09-13-1930.

Тодоров, В. (2000). Етнос, нация, национализъм. Аспекти на теорията и практиката, C., c. $86,25,27,34,36-37,129$.

Тодоров, Ц. (1991). Забележки относно кръстосването на културите. // Литературен вестник, бр. 8.

Туман, М. и Асхойер, Т. (2016). Демокрацията не създава идентичности. Разговор с Франсис Фукуяма. // Култура, бр. 14 (2851), <http://www.kultura.bg/bg/article/view/24644

Хинкова, С. (2010). Динамика на субекта в международните отношения. Възникване, утвърждаване и криза на националната държава. Дипломация и външна политика на великите сили в полицентричната международна среда на XIX в.: Системите „Метерних” и „Реалполитик”. София, Нов български университет, с. 2.

Arnull, A. (1999). The European Union and Its Court of Justice, Oxford University Press, Oxford.

Dimitrova, Snezhana and Naum Kaichev (1999). "The Happiness And Progress Of The Nation Are Attainable Only Provided That Not A Single Part Of This People's Body Hurts...", Balkanistic Forum, Issue 1-3, pp. 56-90.

Engberg, J. (2004). Statutory Texts as Instances of Language(s): Consequences and Limitations on Interpretation, 29 Brook, J. International L., pp. 1135, 1137-39, 1157-61, 1165-66.

Gellner, E. (1983). Nations and Nationalism. Oxford. 
Gray, C. B. (2012). The Methodology of Maurice Hauriou - Legal, Sociological, Philosophical. Editions Rodopi B. V., Amsterdam - New York, NY, p. 151-159.

Hamilton, A. (2011). Herder's Theory of the Volksgeist, http://www.countercurrents.com/2011/05/herders-theory-of-the-volksgeist/.

Ilieva, I. (2008). La protection juridique des personnes appartenant à des minorités en Bulgarie, Hommes \& Migrations Année, 1275, pp. 32-39.

Lawrence M. Solan, (2009). The Interpretation of Multilingual Statutes by the European Court of Justice, Brooklyn Journal of International Law, Volume 34, Issue 2, pp. 23-26.

Marin, N. (2015). Nationalisms Versus Solidarity in Case of EU Law and Security, International conference Knowledge-Based Organization, Vol. XXI, DOI: https://doi.org/10.1515/kbo-2018-0093.

Mitscherlich, W (1931). Volk und Nation in Alfred Vierkandt (ed.), Handwörterbuch der Soziologie (Stuttgart: Ferdinand Enke Verlag), p. 645. 